\title{
THE ANALYSIS OF IMPLEMENTATION OF INDIA'S FOREIGN POLICY, "LOOK EAST POLICY" ON ASEAN INDIA STUDENTS EXCHANGE PROGRAMME PERIOD 2011-2016
}

\author{
Melly Sabina Ester Lengkong \\ International Relations, Universitas Kristen Indonesia, Jakarta, Indonesia \\ mellysabinaesterl@gmail.com
}

\begin{abstract}
This journal analyzes the implementation of India's foreign policy 'Look East Policy' in ASEAN through ASEAN-India Students Exchange Programme (AISEP) in the period 2011-2016. AISEP program is a form of India's Public Diplomacy in ASEAN. The objective of this research is to explore India's goals from the AISEP concerning its foreign policy interests. All the explanations would be associated with the theory of diplomacy and the concept of Foreign policy, Regionalism, and Public Diplomacy. This research implies the qualitative methodology referring to data sources from library research, documentaries, and online. According to data shows that the AISEP program toward disseminating India's modernity in the $21^{\text {st }}$ century ever since its Look East Policy (1992) implemented. The progressive development of India's economy has a positive effect on its foreign policy, which is a matter of interest to Southeast Asian countries, particularly ASEAN. Hence, this research describes the highly economic motivation referring to its dominated industrial visits. Another social and political visits to universities and government institutions were disseminating its growing economy also came from the high quality of its human resources and democracy.
\end{abstract}

Keywords: Look East Policy, ASEAN India Students Exchange Programme (AISEP), ASEAN, Public Diplomacy

DOI: 10.33541/sp.v20i1.1458

Sociae Polites : Majalah Ilmiah Sosial Politik

Faculty of Social and Political Science, Universitas Kristen Indonesia

ISSN 1410-3745 print/ ISSN 2620-4975 online

Volume 20, Number 1 (January - June 2019)

Pages 35-51 


\section{Introduction}

\subsection{Background}

India, part of the South Asia region, was explored by European after the Vasco Da Gama visitation in 1498 (Radakhrisna dan Panda 2006, 1). In 2016, Its population was being the second highest in the world, attaining 1,324 billion citizens (World Bank 2017). After being independent of British colonialization on August, $15^{\text {th }} 1947$, India get classified as the third world country along with another country surrounding Asia in particular. According to its economic circumstance between 1950 to 1990, it was still undeveloped, which was following four percent annual economic progressivity on average. These percentages were lower than Sub Sahara African countries which attained $5.2 \%$. Otherwise, the causality upon poverty along $1987-1990$ was $45 \%$ of its population and known as Hindu growth rate country (World Bank 2017). The desperation economy was affected by the under-planned economy policy since its adoption from Uni Soviet by Prime Minister (PM) Jawaharlal Nehru in tenure.

The policy towards the socialist system in which private property reputed as social crime and its focus on substituting import by emphasizing heavy industries as its economic foundation. Hence, India made itself get blocked to foreign investment as a hindrance to maximizing its inner potentials. For four decades, starting from PM Jawaharlal Nehru (1964-1966), PM Shri Bahadur Shastri (1964-1966), PM Indira Gandhi (1966-1977, 1980-1984), and PM Rajiv Gandhi (1984-1991), India did not reform its economic policy for some points; (1) The dilapidation performance of government concerning to bureaucracy excessive control or License Raj; (2) The inward-looking oriented on political trading; (3) The dilapidation performance of the public companies in the public sector (Winarno 2008, 216). India's economic crisis culminated in 1991 or on post-Cold War (balkanization of Uni Soviet) for Uni Soviet was the main trading partner of India. Thus, regional and global circumstances influenced its crisis. In 1991, PM Pamulaparti Venkata Narashima Rao reformed India's economic policy as a Liberal to attract the private financial sector, disseminate the export, facilitate the foreign investment, resetting up the public companies manage and distribute the national industries competitiveness (Winarno 2008, 219).

Those reformation points also influenced India's foreign policy reformation. The foreign policy consists of its intern policy, which filled up by engaging a deep relation with other countries. The former Indian foreign policy was non-bloc, then changed to be Look East Policy in 1992 to participate in a deep relationship with Southeast Asian countries through ASEAN as a regional organization. The direct objectivity of India through ASEAN is its economic development interest. The establishment background of ASEAN not separated from the post-Cold War avoid itself Uni Soviet of balkanization in purpose (CSIS 1978,7). Since then, ASEAN is a profitable partner of India regarding their upraised partnership status from dialog partner (1996) to strategic partner (2012) along with their values; Peace, Progress, and Prosperity (Asec 2012). ASEAN contributed 9-10 \% of India's export-import trading outcome in the world. In 2015 (Trademap 2017), India gets counted on the seventh-highest economy in the world (World Bank 2017).

Thus, the role of ASEAN was quite significant due to India's economic improvement, and the implementation of Look East Policy in ASEAN countries works tremendously. India keeps improving its relationship with ASEAN, particularly in 
the social sector. India wants to engage its citizen with ASEAN citizens or people to contact people. One of the programs India's government held in the ASEAN India Students Exchange Programme (AISEP). This program contains ASEAN youth. During ten days, those youth visit plants/industries, government institutions, the institution of education, cultural heritage in India. AISEP gives a new comprehension to ASEAN youth in looking at the situational and condition of modern India, particularly in the $21^{\text {st }}$ century. The first program was held in 2007, consisting of 100 youth around 20-28 years old. In 2012, the total number of participants was doubled ups to 250 youth (ASEAN CPP 2016, 2). The facilitators of AISEP are the Ministry of Foreign Affairs of India and the Confederation of Indian Industry (CII). Those facilitators provided quota for 25 youth to the respective Ministry of Youth and Sport or Ministry of Educational and Cultural of ASEAN Member States (AMS). The project proposal given by India to ASEAN Secretary stated that AISEP, along with PM Manmohan Sing, is commemorating the $3^{\text {rd }}$ ASEAN Summit at Vientiane, Lao PDR, in 2004 (Asec 2012). This program focuses on the Plan of Action (POA) as a form of ASEAN-India relationship for peace, progress, and prosperity (2016-2020) and ASEAN Community BluePrint (ACPP 2016, 3). AISEP had stated that POA keeps developing along with the world's development. The first POA (on period 2004-2010) then it keeps continuing on $2^{\text {nd }}$ POA (2010-2015) and $3^{\text {rd }}$ POA (2016-2020).

\subsection{Research Questions}

1. What are India's purposes in ASEAN India Youth Exchange Programme (AISEP)?

2. How does its program become a part of the implementation of India's Foreign Policy, Look East Policy?

\subsection{Purposes and Objectives}

2. To know the purposes of the AISEP that had been facilitated by the Indian government at ASEAN.

3. To know the implementation of India's foreign policy, Look East Policy through AISEP.

\section{Literature Review}

\subsection{Diplomacy and Foreign Policy}

Henry R.Nau stated that diplomacy emphasizes the liberal perspective through converse and negotiations among countries (Nau 2015, 51). Likewise, diplomacy not only directed as a policy instrument but also the entire activity of the implementation and process of policy establishment (Baylis dan Smith 1999, 258). Diplomacy relates to foreign policy and works together. The foreign policy has specific purposes and actions which arranged to persist or alter an object and certain circumstances or to respond to the external sphere (Rudy 2002, 89-90).

Michael Yahuda emphasizes the domestic area to become more considered in determining foreign policy since the complexity of the world sphere (Yahuda 2011, 223). The national interests comprised depictions of state pretension predominantly in 
the future, and opportunities and external obstacles determine the endeavors of achieving those interests. Thus, foreign policy consists of international relations substances or national interests, and diplomacy is a method to accomplish those substances through negotiations (Roy 1991, 33).

\subsection{Regionalism and India's Look East Policy}

India's Look East policy was officially established in 1992 by PM Narashima Rao. Its foreign policy directed to Southeast Asian countries through becoming an ASEAN partner. ASEAN emerged a regional cohesion for its enrolled importantly on Asia regional and could influence other countries in one region. ASEAN united its member to be more powerful either in the economy, security, or social-cultural (Rudy 2002, 84-85). Therefore, India was keen to be a part of ASEAN. The internal and external spheres influenced India's foreign policy. The domestic economy and Uni Soviet's balkanization were the main backgrounds of India's foreign policy reformation. Meantime circumstances encouraged India to look for a potential partner.

Figure 1. Map of Asia Regions

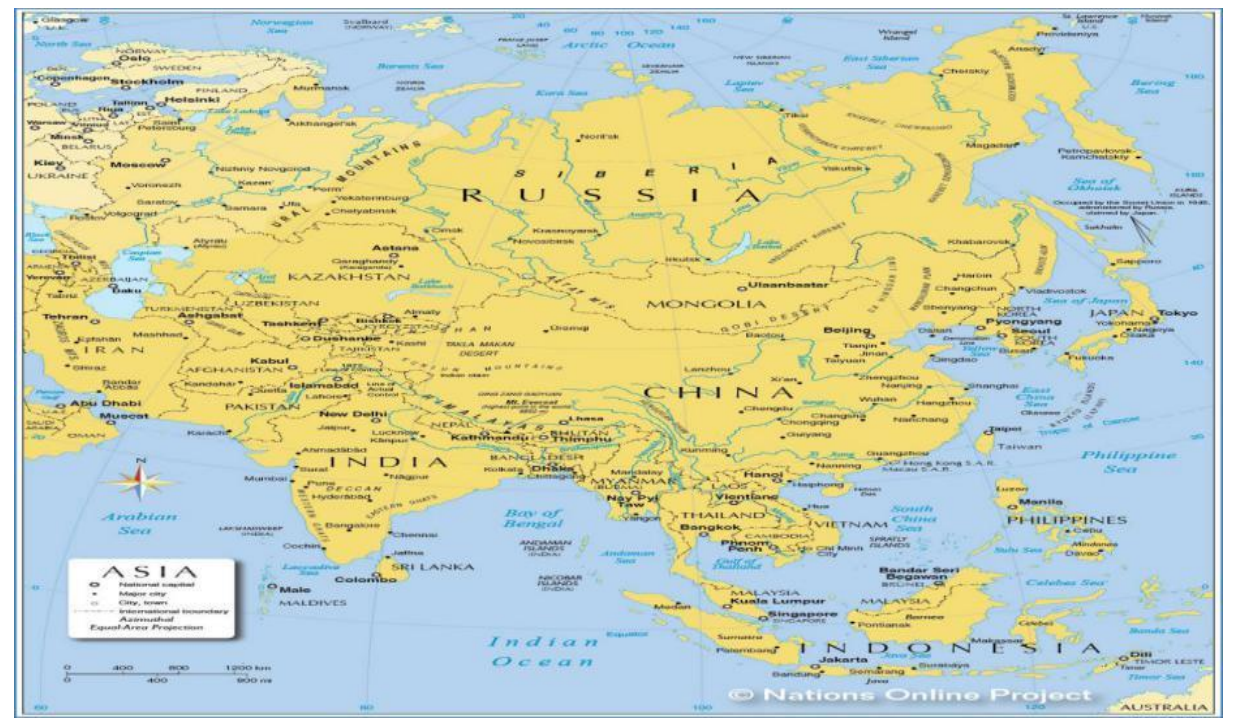

According to South Asia Regional, 'Look to East' rather than looking towards north, south, and west since some clashes with them. Indian point of view, the relations with the west of India (African countries) were not possible since some of them did not become independent; north. Uni Soviets was clashing with the USA and its alliances, and China was Indian rival in regional power; south, predominantly buried of the Indian Ocean and undeveloped country, Sri Lanka. ASEAN was a precious legacy for India meantime. Other considerations for India choose to ASEAN were;

1) ASEAN established in 1967 in the Post-Cold era to increase partnership among its members during the western and eastern conflict;

2) ASEAN land is the closest neighborhood of Eastern India starting with the Myanmar borderline;

3) ASEAN was a profitable partner for their short distances to bring down trading cost;

4) ASEAN united to prevent the domino effect of Cold War (CSIS 1978,7); 
5) On 1990, ASEAN populations were 312.638 people;

6) Meantime, some ASEAN founding countries (Indonesia, Malaysia, and Thailand) were enrolling on top lists countries producer and exporter rubber and tin in the world market.

7) Indonesia, the Philippines, and Thailand were being the largest copra producer in comprising $80 \%$ of world production.

8) Indonesia was the only ASEAN founding countries whose producer of $1.4 \%$ oil of world production.

9) And Singapore was being serviced vendor country to process raw material to semi-finish product and finished product (CSIS 1978, 6).

In brief, ASEAN had a complete package and content for India to achieve its interests consisting of location, distance, market, natural resources, and service vendors. There are five AMS classified on top 25 India export-import partners in the world (Indiatradeportal 2017). Thus, their relationship increased significantly from sectoral (1992) to a strategic partner (2012).

\subsection{Public Diplomacy and ASEAN India Student Exchange Programme}

Public diplomacy is defined as a process to create an international image of all country capabilities in pursuing their diplomatic accomplishments. Also, public diplomacy as an instrument for the actors of state, an association of state, and non-state to understand culture, behavior, and attitude; to influence the thinking and to act of mobilization in increasing its interests and values. The respective activities of states abroad need a transnational citizen's an academician's role in establishing long term relationship (Melissen 2013, 436,437,441). These relations wishfully create a collaboration of economic transactions (Pauline Kerr dan Geoffrey Wiseman 2013, 193).

Public diplomacy or cultural diplomacy breakdowns the cultural barriers for the cultural exchange that occurred between the actors (G.R Berridge 2002, 17). Its diplomacy avails the international point of view for creating constructed personalities through cultural activities. The other benefits are to raise tourism and foreign scholars (Rana 2002, 144-145). One of the India public diplomacy methods throughout the ASEAN India Students Exchange Program (AISEP) facilitated by the Ministry of External Affairs of India Republic (MEA) and Confederation of India Industry (CII). The program started in 2007, comprised of 100 youth (20-28 years old) from 10 AMS representatives. In 2012, those facilitators increased the participants to 250 youth (ASEAN CPP 2016, 2). Those 25 youths get chosen by their respective Ministry of the child of Ministry of Educational and Cultural of ten AMS. During ten days, those delegates visit plants/factories, government - offices, universities, and cultural heritages in several cities of states in India. Namely, Hyderabad, Mumbai, New Delhi, Agra, Bangalore, Pune, Ahmedabad, Chennai, Kochi, and Jaipur. These cities have their specialties.

\section{Research Method}

This research used qualitative methodology in relating to its technical data resourced due to library research, documentary, and online. Following collecting data, resources can get afforded from the books and academic journals in which narrated the 
Look East Policy, India's foreign political histories, and India's influences on Southeast Asia (M. Burhan Bungin 2007, 120). The researcher obtained references from some local libraries at the Christian University of Indonesia, University of Indonesia, Center for Security and International Studies (CSIS), ASEAN Secretariat, and Ministry of Foreign Affairs of Indonesia Republic.

The appropriate data resources also obtained from the documents of; technical guidelines of ASEAN-India Student Exchange Program from Ministry of Youth and Sport of Indonesia Republic, Indian leader statements on ASEAN-India Summit from ASEAN Secretariat, official rundowns on period 2011 to 2016 from CII, and daily reports of AISEP participants on period 2011 to 2016.

The prudent data get obtained from reliable resources via online portals. In terms of official online platforms of Indian government (mea.gov.in), international governmental organizations (asean.org, cii.in, indiantradeportal.in, and data.worldbank.org), and world economic portal (trademap.org).

\section{Results and Discussions}

\subsection{The Implementation of Look East Policy on AISEP}

After implementing the Look East Policy, India's industries overgrow. PM Narashima Rao provided many tremendous opportunities to foreign investment and flexibility of enterprise legality to waive the economic crisis (Bappenas 2017). AISEP is referring to eye witnessing of the youth due to India's economic progressivity after Look East Policy launching. There are three aspects to emphasize that AISEP tendency towards commercial interests, which are goals, actors, and destinations. There are seven main goals of AISEP which are;

1) To build closer people-to-people links between India and ASEAN, particularly among youth of both sides;

2) To inculcate greater awareness and knowledge of India among ASEAN youth and bridge information gaps;

3) To create next-generation connectivity between Indian and ASEAN youth that will facilitate increasing mutual understanding of the two vibrant and dynamic Asian regions;

4) To apprise ASEAN youth about fast-growing sectors of the Indian economy particularly in the knowledge industries (such as IT, Telecom, BPO, etc.) to foster mutually beneficial future interaction;

5) To enable greater economic and academic cooperation between businesses and entrepreneurs of the two sides in preparation for meeting emerging imperatives of closer Asian partnership;

6) To highlight the rich and ancient cultural heritage of India and the historical symbiosis between civilizations of the two sides as reflected in age-old travel, trade, and cultural interchanges;

7) To provide Indian youth an opportunity to learn about ASEAN member- nations through direct interaction with ASEAN students on multimodal platforms in which ASEAN students get taken to IIT, education institutions, where they get the opportunity to interact with each other (CII 2011, 2).

These goals seemed equal between economy and society, yet it's predominantly about exposing India's economy progressivity through youth as 
representative of ASEAN citizens. The social sectors are referring to conversing about cultures, values, tourism, and languages associated with social issues. The economy sector was explicitly referring to the willingness of India to expose, to promote, and to glorify Indian advancements. According to goal number four, it's directed toward on Information and Technology (IT) since its industry brought India to be more prevalent in the world. The economy sector is explicitly referring to the willingness of India to expose, to promote, and to glorify Indian advancements. Several IT industries succeed in unfurling itself be abroad, such as Infosys, Wipro, and Tata Consultancy Service (TCS). Those goals get implemented on visit destinations to sectors. 
Figure 2. ASEAN-India Export-Import from 2001 to 2016 (In US\$ Thousand)

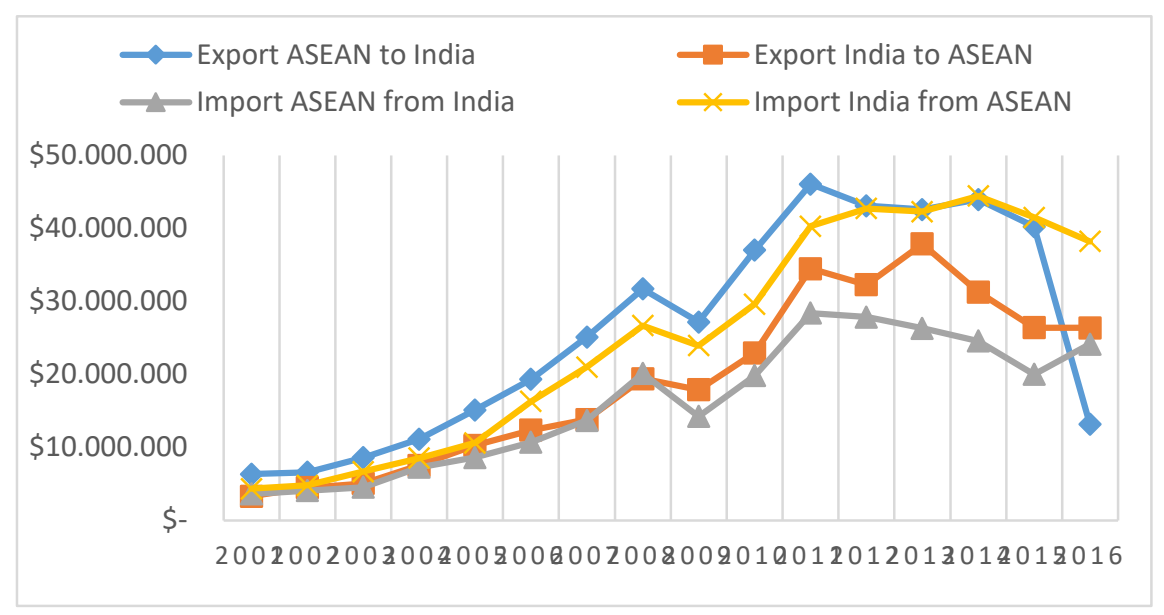

Those economic goals also influenced by ASEAN-India economic partnership improvement. The ASEAN-India export-import revenue from 2007 to 2011 resulted in a significant total in which the highest values in 2011 attained US\$ 46,079 million (ASEAN export to India). The upraised transaction affected the number of the AISEP participant in a double which multiplied to 250 people (since 2011). Those people get offered special facilitates by the facilitators'. Namely, free visa expenses since the MEA sent the free approval to the Indian Embassy on the respective of AMS, international flight vice versa, meals, inns, local transportations, local attractions ticket, and pocket money of 6000 Rupees to each delegate. That amount equals to minimum wages for educated workers at New Delhi for ten days (622 Rupees/day) (delhi.gov.in, 2017). The facilitators covered all of the accommodations. India-ASEAN Cooperation Fund bears the budget for AISEP. These things explain that India pays attention to a deeper relationship with ASEAN for eliciting the big profit to India (CII 2011, 2). Moreover, In the $21^{\text {st }}$ century, India's economy is emerging up and proving by its rank as the $7^{\text {th }}$ largest world economy in 2015 (World Bank 2017).

\subsection{AISEP: To Expose Indian Economy Power}

Indian economy's primary goal as AISEP facilitators whom they work with and the tendency to visit destinations. In terms of public diplomacy and economy frameworks, CII and MEA work together as AISEP's facilitators to achieve both interests. CII, established in 1895, is a nonprofit association that is lead and managed by industrial organizations, either private or public sectors. CII plays an active role in the Indian development process. CII purposes to conducive and maintains a pleasant vibe to develop India's economy, engage with industries, governments, and citizens in the way of consultation (CII 2017). Therefore, the connectivity was comprised of industrial visit thoroughly. 
Figure 3. AISEP Visit Sectors from 2011 to 2016

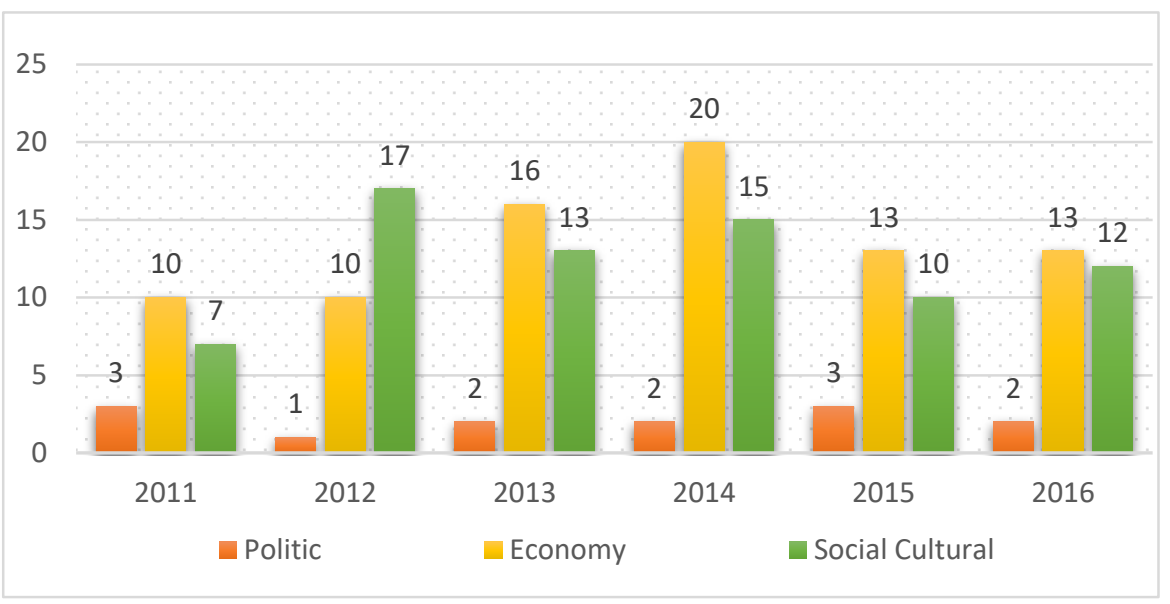

Source: Confederation of Indian Industry, arranged by researcher 2017.

According to chart 4.2 exposes that the economic destination visits predominantly comprising than political and social-cultural. The way of social and political agenda was covering those commercial interests since they were all related to each other. Those sectors mostly located in the big Indian cities, which has a lot of significant impacts on the Indian financial industry. Between 2011-2016, the cities of the states visited were Mumbai, Hyderabad, New Delhi, Bengaluru, and Agra. Mumbai is the wealthiest city in India and the highest GDP in South Asia and West Asia or Central Asia. Mumbai includes on the top ten World Trade Center in the world and contributes to the 5 percent of its revenue to India's GDP (CII 2013, 3). Hyderabad is known as The Silicon Valley of India after Bengaluru. Many Multinational Companies (MNCs) such as Microsoft, IBM, and Wipro, built their offices. New Delhi is India's capital city and becomes the field for the central of Indian government activities (CII 2013, 4). Bengaluru is a symbol of Indian hold on the Information and Technology sector. More than five hundred international companies have their branch offices there. Almost 70 percent of the USA IT companies placed their office at Bangalore. One of the biggest IT companies in India, Infosys, also built its office. Hence, Bengaluru is known as The Silicon Valley of India. Then, Agra is a famous city because of the Taj Mahal heritage site and Agra Fort as an inheritance of Mughal Imperium (CII 2013, 3).

It was related to AISEP destinations in three sectors (economic, political \& social-cultural). The most intensive industries (commercial) visited were Tata Consultancy Service, Tata Boyce, dan Tata Motor; CII - Sohrabji Godrej Green Business Centre; L\&T, Ltd; Bombay Stock Exchange, Ltd; Godrej \& Boyce Mfg Co Ltd; Maruti Suzuki; Sona Koyo Steering System, Ltd; Wipro, Ltd; National Stock Exchange; Sandhar Technologies, Ltd; TVS Motor; Mahindra World City; Infosys/Genpact. Those big industries enhanced the Indian economy (Economictimes 2016). On the social and politic sector, the most intensive visit destinations were Whistling Woods International (WWI), Indian School of Business (ISB), Indian Institute for Technology (IIT), Indian Economic School Management College (IESMC), Indian Institute of Management (IIM), Taj Mahal, Qutub Minar, Humayun Tomb, Jaigarh Fort, Agra Fort, Amber Forth, Indian Election Commissioner (IEC) and Foreign Service Institute (FSI). Those industries of automotive and Technology of Information (IT) are always to be visited annually in the period 2011-2016. The visits 
to the social and political sectors were supporting the other sites of India's economic progressivity.

\subsection{India's Power in Information \& Technology Industries}

Information \& Technology (IT) industries always are consisted of AISEP schedule activities, particularly in 2011-2016. It caused by Indian capability in IT (21 ${ }^{\text {st }}$ century). The table below exposes Indian achievements in IT industries.

Table 1. The Achievements of India's IT Industries

\begin{tabular}{|c|l|}
\hline No. & \multicolumn{1}{|c|}{ Achievements } \\
\hline 1. & $\begin{array}{l}\text { We are providing opportunities in the private sector to more than 3,1 } \\
\text { million job opportunities. }\end{array}$ \\
\hline 2. & IT sector contributed 38 percent of India export service. \\
\hline 3. & IT service export revenue to US\$ 52 billion. \\
\hline 4. & $\begin{array}{l}\text { The engineering service, research \& development, software products } \\
\text { get exported to US\$ 14 billion. The hardware industries shipped to } \\
\text { US\$ 0,4 billion. }\end{array}$ \\
\hline 5. & $\begin{array}{l}\text { Sixty percent of companies in the world are hiring India's tested } \\
\text { service. }\end{array}$ \\
\hline 6. & $\begin{array}{l}\text { The Indian IT industries attained } 7 \% \text { in the global market, } \\
\text { particularly from export. }\end{array}$ \\
\hline
\end{tabular}

Source: Indian Embassy, Make in India, 2016, 26.

The export revenue of Indian software industries (1991-1992) grew up to $35 \%$ and contributed to $70 \%$ of 73 national software companies. In the years 2005-2006, the profit from the software export and service was around US\$22,43 billion (Kompas 2007, 36). This growth also came from the increase in higher-skilled workers such as research and engineering. The era digital had provided more job opportunities to Indian products in computer and technology, biotechnology, and medical sciences. The developed countries such as the USA, Germany, Japan, and Canada pervaded Indian IT specialists (Sondhi dan Tyagi 2001, 20). Those benefits are part of India's dreams. After India's independence, the Indian government sent thousands of their chosen youth people to study IT in the USA and Europe. Through capabilities and skills, they're hired as IT specialists at the silicon valley of the USA, spreading out from San Francisco to San Jose. More than half percent of 150.000 foreign workers were from India. Those requirements not only because of their IT skills but also English proficiency and low wages. From the 1980 s to the early 1990 s, there was an IT specialist pilgrimage to their national land and developed its own IT system and known as The Silicon Valley (Kompas 2007, 36). Those valleys consist of more than 200 IT companies, including Google and Microsoft (Kompas 2007, 37).

Infosys, Wipro, and Tata Consultancy Service (TCS) are three giant IT companies that influence ASEAN. Infosys is one of the Indian companies at the NASDAQ share market (Arcilla and Cabrera 2016, 10). Infosys expands its branches in Asia Pacific Region (Australia, Tiongkok, Hong Kong, India, Japan, Malaysia, New Zealand, and Singapore). Malaysia and Singapore become Infosys's headquarter in Southeast Asia to reach other Southeast Asian countries. Singapore has a strategic role 
in a company's operation ever since a New Development Center of Infosys had built there and deployed more than 600 new engineers and other professionals. Singapore has excellent infrastructures and human resources on more than 8.000 young IT Engineers in annual (Infosys 2011). Wipro has outsourcing globally more than 170.000 employees in servicing its clients in more than 175 cities in 6 continents such as Asia, Europe, North America, South America, Middle East, and Africa. In Asia, Pacific Wipro attends on Australia, Japan, Tiongkok, Taiwan, Indonesia, Malaysia, Philippines, and Thailand. In 2013, Wipro accomplished the Business Intelligence Services on the Asia Pacific by Independent Research Firm (Wipro 2017). TCS is an IT service provider company whose is being one of the largest IT company in India, TCS has more than 318.000 trained IT consultants in 46 countries (Kompas 2007, 19). TCS headquartered in Mumbai and entered National Stock Exchange and Bombay Stock Exchange India (TCS 2016-2017, 1). TCS has many branch offices in North America, Latin America, Europe, Middle East, Africa, Australia, New Zealand, and Asia. Its branches in Asia consists of Bangkok, Hong Kong, Indonesia, Japan, Malaysia, Philippines, Singapore, South Korea, Taiwan, and Thailand (Worldwide 2017).

Moreover, Singapore had been collaborating with TCS to produce Smartwatch to enhance ground handling operations at Changi International Airport in Singapore. Southeast Asia had a big roll in TCS marketing (TCS 2017). Likewise, in the 2016-2017 Singapore government classified on the top six TCS shareholders who invested 0.5 percent shares. In Indonesia, TCS deployed 6500 job opportunities (TCS 2016-2017, 105).

\subsection{India's Power in Automotive Industries}

The automotive industries of India have a significant role in local economic development. The table below exposes Indian achievements in automotive industries.

Table 2. The Achievements of India Automotive Industries

\begin{tabular}{|c|l|}
\hline No. & \multicolumn{1}{|c|}{ Achievements } \\
\hline 1. & $\begin{array}{l}\text { The } 7^{\text {th }} \text { biggest in the world of vehicle producer with annual production to } \\
17,5 \text { million in average whereon } 2,3 \text { million get exported. }\end{array}$ \\
\hline 2. & The $4^{\text {th }}$ biggest automotive market on volume-based in the world (2015). \\
\hline 3. & The $4^{\text {th }}$ position of central world manufactures. \\
\hline 4. & It is contributing to India's GDP at almost 7 percent. \\
\hline 5. & $\begin{array}{l}\text { India as the } 2^{\text {nd }} \text { biggest of motorcycle and the } 5^{\text {th }} \text { biggest in the world on } \\
\text { commercial vehicle manufacture. }\end{array}$ \\
\hline 6. & The total sale in 2010-2011 attained US\$ 58,5 billion. \\
\hline
\end{tabular}

In 2006, the total export of all Indian car manufactured attained 1.170.193 vehicles. They are highly innovative in new products and services. In the national framework, Tata Motors was able to set aside other competitors such as Toyota, Honda, Hyundai, and Suzuki. On the list of The Most Respected Companies version The Business World, the top four companies were local Indian companies; (1) Tata Motors, (2) Mahindra \& Mahindra, and (4) Bajaj Auto. Those companies were being independent in design and model improvement (Kompas 2007, 85). Automotive 
industries hired more than 450.000 workers and offered more than 10 million job opportunities. Its industries flowed 4 percent to India's GDP in 2003-2004, which higher than 1992-1993, 2,77\% (Kompas 2007, 86). The Indian government obligates foreign companies to consist of $70 \%$ local components in their products and training the local partners. Hence, the domestic component industries grow along with the Indian assembled industries since India able to provide its automotive components need (Kompas 2007, 90).

Automotive companies such as Maruti Suzuki (MS) and Tata Motors (TM) were the dominant destinations in AISEP visitation. These companies have a significant influence in Southeast Asia. TM had expanded its victory to the Southeast Asia market, such as Indonesia, Vietnam, Thailand, Philippines, Myanmar, and Malaysia. Tata had significant interests in six AMS, as depicted in the following table 4.5 (Tata 2016).

Table 3. Tata Motors Motivations at The ASEAN Member States

\begin{tabular}{|c|c|c|}
\hline AMS & $\begin{array}{l}\text { Year of } \\
\text { Entry }\end{array}$ & Motivations \\
\hline Indonesia & 2012 & $\begin{array}{l}\text { To achieve the top } 10^{\text {th }} \text { national automotive trade of } 39 \text { brands in } \\
\text { Indonesia. To enter the top } 10^{\text {th }} \text { rank on top } 10^{\text {th }} \text { world automotive } \\
\text { market. To maximize the significant opportunities in Indonesia } \\
\text { and to lodge the high } 10^{\text {th }} \text { global automotive market. To make } \\
\text { Indonesia as the } 2^{\text {nd }} \text { biggest market out of India. }\end{array}$ \\
\hline Vietnam & 2015 & Vietnam enrolled as an essential market in the Asia Pacific \\
\hline Thailand & 2008 & $\begin{array}{l}\text { Thailand is one of the biggest economy countries in Southeast } \\
\text { Asia. }\end{array}$ \\
\hline Philippines & 2014 & $\begin{array}{l}\text { The affordability of purchasing and the exceeding of diesel } \\
\text { vehicles. }\end{array}$ \\
\hline Myanmar & 2013 & TM built an assembling plant at Magwe, Central Myanmar. \\
\hline Malaysia & 1974 & $\begin{array}{l}\text { Malaysia as the top } 4^{\text {th }} \text { position of the economy, collaborating } \\
\text { with its distributor partner, DRB-HICOM Commercial Vehicles } \\
\text { Sdn. Bhd (DHCV) and likelihood can get enrolled in Malaysia's } \\
\text { economic growth. }\end{array}$ \\
\hline
\end{tabular}

These motivations in six AMS (Indonesia, Vietnam, Thailand, Philippines, Myanmar, and Malaysia) are a significant market for TM existence. Malaysia is the longest market country of TM. Even though Indonesia is the youngest market of TM, yet it is the most expensive and profitable market for TM. The main goal of TM in Indonesia is superb significant to become the $2^{\text {nd }}$ biggest TM market out of India. Also, Myanmar plays a vital role in the TM market even since the assembling plant to reach the Asia Pacific market built there. Likewise, the Philippines provides a big market for selling diesel machine cars.

MS is a joint venture company between Japan and India. MS has more than 1000 robots for car production. $95 \%$ production using a robotic system and $5 \%$ of humans. MS is the most common private vehicle in India. These machines and spare parts imported from Japan and Germany. The production process takes 12 seconds for each car (Lengkong 2015, 10). Suzuki expanded to India as Japan's global strategy to be fourth Japan's most significant producer after Toyota Motor, Honda Motor, and Nissan Motor. It's targeting three billion units in 2009, comprising 1,24 million of 
Japan's production and 1,76 million from overseas plants (Kompas 2007, 83). MS exports its spare-parts to many regions included Southeast Asia countries such as Indonesia, Thailand, Myanmar, Lao PDR, Vietnam, and the Philippines. On November 3rd, 2016, the highest export was Myanmar for more than US\$ 1.270 million, Indonesia, for more than US\$ 578 million, and Malaysia US\$ 528 million (Seair 2017). Indonesia was the highest MS export destination attained US\$ 524 million. Malaysia and Lao PDR are the potential destinations market to get explored (Marutistorage 2011).

\subsection{AISEP: To Expose India's Merged Power of Education and Politics}

The visits to the universities and government made to emphasize that Indian development also supported by its competent human resource and good governance. India consistently (2011-2016) emphasizes its IT, engineering, business, and film education through visiting WWI, ISB, and IIT. WWI, located in Mumbai, is known as the biggest broadcasting, animation, and filming school in Asia. Almost 15 percent of WWI students are from Germany, England, the USA, Canada, Italia, France, Netherland, and Vietnam. WWI's alumni work at India's famous production houses, such as Amir Khan Productions, Annapurna Studios, BIG Animation, Balaji Telefilms, and Dharma Productions. The ISB, collaborating with the London School of Business, is a world-class business school in Asia. It was established by Indian corporation leaders to create capable entrepreneurs, particularly in Asia and India. Its graduates expected to get actively enrolled in India's economic acceleration on global enterprises. Its students get freed to use electronic devices during lectures to ease information access to the subject. ISB employs an anti-wysiwyg system (what you see is what you get); for someone beliefs, are not necessarily believed by others (Delegasi Indonesia 2016, 5). IIT is the best technical institute in India. IIT was ranked $36^{\text {th }}$ and $50^{\text {th }}$ among the best world universities. One IIT alumnus is NR Narayana Murthy as the founder of Infosys, one of the biggest IT companies in India. Vinod Khosla, the founder of Sun Microsystem, USA, is also an IIT alumnus (Kompas 2007, 56-57). Those universities interacted with AISEP participants to be the next scholars through campus presentations.

India is the largest democratic country in the world and holds elections per five years. AISEP delegates visited the election held by Indian Election Commissioner (IEC). IEC was established on January 25th, 1950, and succeeded in transforming the Indian election system to digital. IEC gets tasked to observe and facilitate elections. They are involved in voting education from primary education to higher school to enhance the participation of vulnerable Indian youth in elections (Arcilla and Cabrera 2016, 27). The digital system should be more useful for India's population of more than 1,3 billion (Worldbank 2017). There are several advantages of the digital network, such as being paperless, no cheating, and a shorter collection time-less than 3 hours after voting ends. Those improvements occur because of its power in the IT system (Lengkong 2015, 12).

The Foreign Service Institute (FSI) is associated with the MEA since it is a place that develops superb future Indian diplomats. It is a place concerned with elaborating and promoting Indian interests at ASEAN to AISEP participants. This gets directly stated by the diplomat speakers, Mr. Ashok Sajjanhar, in 2015. He explains India's focus on AMS relations (Indonesia, Malaysia, Cambodia, Lao PDR, Myanmar, Singapore, Brunei Darussalam, Thailand, Philippines, and Vietnam) and its neighboring countries 
(Pakistan, Nepal, and Bhutan). It followed the Indian Look East Policy, which has existed for more than 20 years - from 1992 to 2014 - as India foreign policy. Through visiting FSI, the AISEP participants got a full package of India motivations for holding this youth program. It's fully accommodated India's interest in exposing its capabilities and improvements in the economy associated with social and political sectors. FSI embedded the Indian foreign policy to AISEP participants to be more acknowledged and propagated.

\section{Conclusions and Recommendations}

\subsection{Conclusion}

Diplomacy relates to foreign policy and works together to achieve national interests. The "Look East" policy associated with ASEAN illustrates the dynamic power between policy and policy purposes. By engaging diplomacy with ASEAN, India is trying to promote its economic interest. ASEAN-India diplomatic relations strongly tied to the strategic partnership between them. ASEAN facilitated high profit for India and got included in the top 25 export-import partners. The new economy of India ( $21^{\text {st }}$ century) is far contrary to India's image in the 1990s. Multinational companies are aggressively investing in India. One can see the contrast in depicting India before and after the Look East Policy implemented. ASEAN had a significant role in Indian economic improvement.

The ASEAN India Students Exchange Programme (AISEP) is one implementation of India's public diplomacy in terms of highlighting Indian economic development in the $21^{\text {st }}$ century. Foreign policy has specific purposes and actions that designed to persist or alter an object and certain circumstances or to respond to the external sphere (Rudy 2002, 89-90). The foreign policy consists of international relations or national interests, and diplomacy is a method to achieve those national interests through negotiations (Roy 1991, 33). India Look East Policy promotes India's national interests by accelerating the Indian economy. India encourages its ASEAN partners to be conscious of India's progress. India set up AISEP as a complete package, including sectoral visits - economic, social, and political, though the commercial sector accentuated. These goals, actors, and destinations geared towards economic interests. From 2011 to 2016, the sectoral industrial visits (destinations) were comprised predominantly than official, heritage sites, and universities.

It emphasized that India desires to show its modernity to youth through AISEP. Exposing the Indian economy progressively through sectoral visits is the primary goal of India. India was able to share its development and economic values with AISEP participants during the tour. The main actors in its program are the facilitator, MEA, and CII. They worked together to pursue their economic goals. The Indian global companies such as TCS, TM, MS, Infosys, dan Wipro get prioritized. They have tremendous influences and interests that ASEAN countries become the next market leader in the Asia Pacific. Indonesia is the main target of automotive companies since TM and MS had had a significant profit from its export revenue. Visiting other sectors (political and social-cultural) are complementing Indian economic improvement. These facilitators exposed their country powers aside from the economy. Visiting WWI, ISB, and IIT showed the quality of Indian education and the ability of India to balance its economic improvement with schooling. Visiting IEC highlighted India's silver lining of 
its election system following its mass population. The visit ended to FSI to emphasize and to embed that AISEP as a part of India Look East Policy implementation. This program can enhance relationships for the future. Moreover, AISEP was able to impart its values, cultures, and powers to ASEAN youth as the upcoming leaders.

\subsection{Recommendations}

Applying the title of the ASEAN-India Students Exchange Programme is not suitable because there are no representative students from India. Adding some days for having a real-life Indian family through a homestay. This experience will be more reflecting on the culture of the Indian people. AISEP should have an official alumni platform under MEA and CII. It would be a way to follow up and communicate with its alumni.

Then it becomes a more insightful platform for sharing valuable information and experiences. Therefore, the people to people contact between India and ASEAN could be more meaningful even though it is out of the program sphere. 


\section{BIBLIOGRAPHY}

\section{Books}

Baylis, John dan Steve Smith. 1999. The Globalization of World Politics: An Introduction to International Relations. New York: Oxford University Press.

Berridge, G.R., 2010. Diplomacy Theory and Practice Fourth Edition. Hampshire: Palgrave Macmillan.

Bungin, M. Burhan. 2007. Penelitian Kualitatif. Jakarta: Kencana.

Center for Strategic and International Studies (CSIS). 1978. Dokumentasi: ASEAN Dalam Berita, Harapan dan Kenyataan 1967-1977. Jakarta:CSIS.

Kerr, Pauline dan Geoffrey Wiseman. 2013. Diplomacy In A Globalizing World: Theories and Practice. New York: Oxford University.

Kompas. 2007. India: Bangkitnya Raksasa Baru Asia. Jakarta: Kompas.

Melissen, Jan. 2005. The New Public Diplomacy. New York: Palgrave Macmillan.

Nau, Henry R., 2015. Perspectives on International Relations: Power, Institutions, and Ideas Fourth Edition. California: CQ Press.

Rana, Kishan, S., 2002. Inside Diplomacy. New Delhi: Manas Publications.

Roy, S.L. 1991. Diplomasi. Jakarta: Rajawali Pers.

Rudy, T. May. 2002. Studi Strategis: Dalam Transformasi Sistem Internasional Pasca Perang Dingin. Bandung: Refika Aditama.

Sondhi, ML dan KG Tyagi. 2001. India in the New Asia-Pacific. New Delhi: Manas Publications.

Winarno. Budi. 2008. Pertarungan Negara VS Pasar . Jakarta: Media Pressindo.

Yahuda, Michael. 2011. The International Politics of the Asia-Pacific Third and Revision Edition. New York: Routledge.

Articles

CII. 2011. “ASEAN-INDIA Student Exchange Programme: Building Youth Partnership Through Entrepreneurship." New Delhi. Confederation of Indian Industry.

2013. "ASEAN Students Exchange Program: Program for Group 2 (As on 18.9.13)." New Delhi. Confederation of Indian Industry.

\section{Reports}

ASEAN Secretariat. 2012. ASEAN-India Eminent Persons' Report To The Leaders. Jakarta: Public Outreach and Civil Society Division ASEAN Secretariat.

ASEAN Cooperation Project Proposal. 2016. ASEAN India Students Exchange Programme. Jakarta. Public Outreach and Civil Society Division ASEAN Secretariat.

Arcilla, John dan Nonito Cabrera Jr. 2016. AISEP 2016 Post-Programme Reports and Reflections - Philippines Delegation. Philippine. Philippines Delegation.

Delegasi Indonesia. 2016. Laporan Perjalanan ASEAN Students Visit India (ASVI) 2016. Jakarta: Delegasi Indonesia.

Lengkong, Mely. 2015. Laporan Kegiatan Program ASVI 2015. Jakarta: Mely Lengkong. 
Tata Consultancy Service. 2016-2017. Annual Report: Reimaging The Enterprise. Mumbai: Tata Consultancy Service.

\section{Magazines}

Kedutaan Besar India. 2017. Make In India: Membuat di India. Jakarta: Kedutaan Besar India.

\section{Websites}

ASEAN Secretary, 2012. "ASEAN-India Partnership for Peace, Progress and Shared Prosperity" Accessed on June 12nd, 2017. http://asean.org/?static_post=asean-india-partnership-for-peace-progress-and-s hared-prosperity-2.

Antara 2009. "Maut Mengintai di Jalanan Hyderabad." Accessed on June 20nd, 2017. http://antaranews.com/berita/152068/maut-mengintai-di-jalanan-hyderabad.

Bappenas 2008 “ Ekonomi India Tinggal Landas" Accessed on June 12nd, 2017. https://www.bappenas.go.id/files/5413/5228/3043/ekonomi-india-tinggal-land as_20081123060433__1002_0.pdf

Delhi.gov.in 2017. "Current Minimum Wage Rate." Accessed on August 18th, 2017. http://www.delhi.gov.in/wps/wcm/connect/doit_labour/Labour/Home/Minimu $\mathrm{m}+$ Wages/.

ET 500 Companies 2016. "Super 50 Companies 2015.” Accessed on June 1" 2017. http://economictimes.indiatimes.com/marketstats/pid-57,pageno-1,sortby-Curr entYearRank,sortorder-desc,year-2016.cms

Indiatradeportal. 2017. "India's Top 25 Export Destinations." Accessed on June 12nd, 2017. http://indiantradeportal.in/vs.jsp?lang=0\&id=0,25,45,858,859.

Maruti Suzuki, 2011. "Technological." Accessed on June $28^{\text {th }}$. https://marutistorage.blob.core.windows.net/marutisuzukipdf/AR-10-11.pdf

Nations online in 2017. "Map of Asia ." Accessed on July 3 ${ }^{\text {rd }} 2017$. http://www.nationsonline.org/oneworld/asia_map.htm

Seair 2017. "Details of Maruti Suzuki Export Data." Accessed on June 28 ${ }^{\text {th }}, 2017$. ttps://seair.co.in/maruti-suzuki-export-data.aspx

Tata Motors, 2017. "Worldwide." Accessed on June $28^{\text {th }}$, 2017.http://www.tatamotors.com/worldwide/.

TCS 2017. "TCS Worldwide." Accessed on June $28^{\text {th }}, 2017$ http://worldwide.tcs.com/worldwide/Pages/default.aspx

Trade map 2017. "Bilateral trade between India and the Association of South-East Asian Nations (ASEAN) Product: TOTAL All products." Accessed on June 12nd,

2017.http://www.trademap.org/Bilateral_TS.aspx?nvpm=1|699||24|TOTAL|||2 |1|1|1|2|1|1|1|

Wipro 2017. "About and History." Accessed on June $19^{\text {th }}, 2017.7$ http://wipro.com/about-wipro/.

World Bank, 2015. "Gross domestic product, 2015." Accessed on June 19 ${ }^{\text {th }}, 2017$, http://databank.worldbank.org/data/download/GDP.pdf. 